\title{
Rancang Bangun Buck-Boost Converter Pada Sistem Charging Baterai dengan Sumber Solar Cell Menggunakan Kontrol PI pada Uninterruptible Power Supply (UPS) Offline untuk Aplikasi Beban Rumah Tangga
}

\author{
Yeheskiel Rante Payung, Era Purwanto, Farid Dwi Murdianto \\ Program Studi D4 Teknik Elektro Industri \\ Politeknik Elektronika Negeri Surabaya \\ era@pens.ac.id
}

\begin{abstract}
Abstrak - Kasus pemadaman listrik bergilir sudah menjadi masalah umum di Indonesia. Kebutuhan listrik semakin memuncak karena penggunaan energi listrik dapat menghidupkan berbagai peralatan rumah tangga dan industri. Saat ini, banyak terjadi pemadaman listrik secara bergilir karena kapasitas beban sudah melebihi kapasitas yang sudah ditentukan. Akibatnya, pasokan energi listrik menjadi tidak stabil, sehinga berdampak pada peralatan listrik rumah tangga. Akibat pemadaman listrik yang tidak menentu maka digunakan pemasok cadangan yang dapat bekerja ketika sumber daya utama tidak aktif atau disebut UPS (Uninterruptible Power Supply). UPS dapat menjadi energi cadangan listrik sementara pada saat terjadi pemadaman listrik sehina mengurangi dampak pada peralatan listrik rumah tangga. Pada perancangan sistem ini, digunakan sumber solar cell 300WP (watt peak) yang digunakan untuk proses pengisian baterai 48V DC 45Ah dengan menggunakan buck-boost converter. Ketika sumber utama PLN tidak aktif ATS (Automatic Transfer Switch) secara otomatis akan memindahkan catu daya dari baterai. Dari sumber baterai digunakan inverter satu fasa untuk mencatu beban rumah tangga sebesar $50 \mathrm{~W} 220 \mathrm{~V}$ AC.
\end{abstract}

Kata kunci: pemadaman listrik, UPS, buck-boost converter, inverter satu fasa

\section{Pendahuluan}

Saat ini, dengan semakin berkembangnya teknologi di dunia, kebutuhan energi terutama energi listrik semakin meningkat [1]. Kasus pemadaman listrik bergilir sudah menjadi masalah yang umum di Indonesia, khususnya didaerah luar pulau jawa [2]. Kebutuhan penggunaan peralatan listrik semakin meningkat sehingga sumber energi listrik tidak mampu memenuhi pasokan listrik [3]. Akibatnya, terjadi pemadaman listrik secara bergilir karena kapasitas beban sudah melebihi kapasitas yang sudah ditentukan. Khusus pada energi listrik, kebutuhan pasokan listrik yang stabil dan terus-menerus sangat dibutuhkan oleh hampir seluruh pengguna baik itu personal maupun industri. Oleh karena itu, untuk menghindari terjadinya pemadaman listrik dibutuhkanlah pemasok daya cadangan untuk menjaga pasokan energi listrik stabil/kontinu menggunakan sistem Uninterruptible Power Supply [4]. UPS adalah peralatan listrik yang berfungsi untuk mencatu daya sementara saat daya utama dari jaringan padam. Daya sementara ini bersumber dari DC yang disimpan dalam baterai. Sistem UPS dapat dihubungkan dengan beban-beban yang sensitif/kritikal seperti peralatan medis, sistem komunikasi/jaringan, transaksi finansial, dan lain sebagainya [3], [5]. Ketika catu daya dari jaringan utama padam, bebanbeban kritikal ini tetap mendapatkan catu daya dari UPS. Selama terjadi gangguan pada sumber listrik utama, maka UPS akan menyuplai kebutuhan daya beban.

UPS dapat dikategorikan dalam beberapa tipe, yaitu UPS line interactive, UPS online, dan UPS offline [5]. Pada UPS offline saat terjadi gangguan, beban akan merasakan interupsi daya akibat proses pemindahan saklar dari jaringan utama PLN ke sumber cadangan seperti solar cell, turbin, atau generator. Pada sistem ini bertujuan untuk merancang dan membangun suatu sistem pemasok daya cadangan (UPS Offline) dengan sumber Solar cell menggunakan saklar otomatis berupa ATS (Automatic transfer switch) dalam proses pemindahannya untuk mencatu beban rumah tangga 50W.

\section{Perancangan Sistem}

Perancangan UPS (Uninterruptible power supply) Offline pada aplikasi beban rumah tangga dengan daya 50W ini mengunakan dua sumber dalam satu garis aliran daya. Dua sumber tersebut yaitu dari PLN dan dari baterai 48V DC 45Ah. Ketika sumber PLN tidak aktif maka ATS secara otomatis mengubah aliran sumber daya ke Baterai yang digunakan untuk supply daya beban. Sumber solar cell 300WP digunakan untuk mengisi daya pada baterai 48V DC 45Ah menggunakan buckboost converter dengan tegangan charge 57,6V DC. Dari baterai dihubungkan inverter satu fasa yang akan mengubah tegangan $48 \mathrm{~V}$ DC menjadi 33,94 V AC yang selanjutnya dihubungkan dengan LC filter dan transformator step up untuk menaikkan tegangan menjadi 220V AC. Proses pengaturan PWM (pulse width modulation) untuk mengatur duty cycle menggunakan kontrol PI pada buck boost converter dan SPWM (Sinusoidal pulse width modulation) pada inverter satu fasa 
dalam sistem ini menggunakan mikrokontroller STM32F4. Bentuk blok diagram yang akan dirancang ditunjukkan seperti pada Gambar 1.

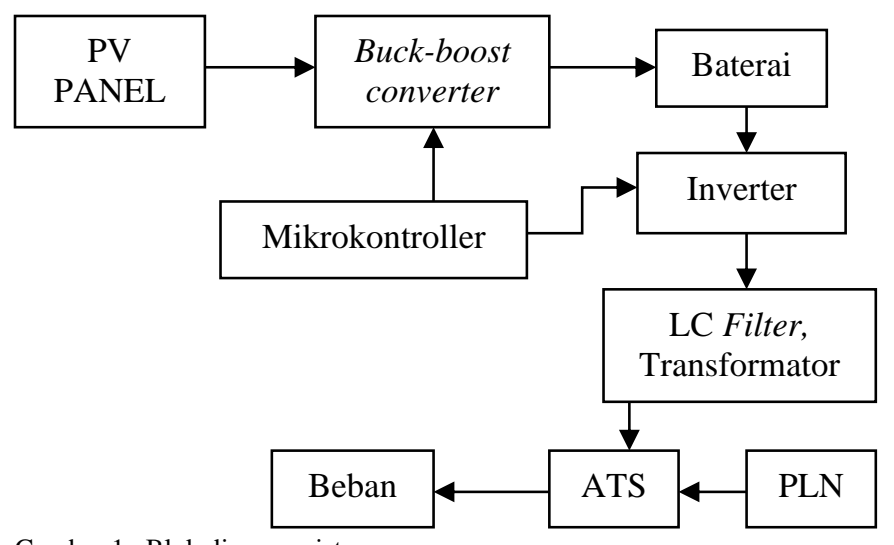

Gambar 1. Blok diagram sistem

Kalkulasi kebutuhan beban dan spesifikasi atau rating daya setiap beban dapat ditunjukkan pada Tabel 1 .

TABEL 1

ESTIMASI DAYA BEBAN

\begin{tabular}{|c|c|c|c|c|}
\hline No & Beban & Daya(W) & Jumlah & $\begin{array}{c}\text { Total Daya } \\
\text { beban (W) }\end{array}$ \\
\hline 1 & $\begin{array}{c}\text { Adaptor HP 5V DC; } \\
\text { 2A }\end{array}$ & 10 & 3 unit & 30 \\
\hline 2 & Lampu & 10 & 2 unit & 20 \\
\hline \multicolumn{3}{|c|}{ Total daya beban keseluruhan } & 50 \\
\hline
\end{tabular}

\section{A. Perancangan Buck-Boost Converter}

Prinsip kerja buck-boost converter dimana tegangan input dapat lebih besar atau lebih rendah dari tegangan keluaran [6]. PWM pada buck-boost converter tergantung pada nilai D (duty cycle). Bila $\mathrm{D}>0,5$ maka tegangan output akan lebih besar dari tegangan input, sedangkan bila $\mathrm{D}<0,5$ maka tegangan output akan lebih kecil dari tegangan input, dan tegangan input sama dengan tegangan output saat $\mathrm{D}=0,5$ [7]. Rangkaian buck boost converter dapat dilihat pada Gambar 2.

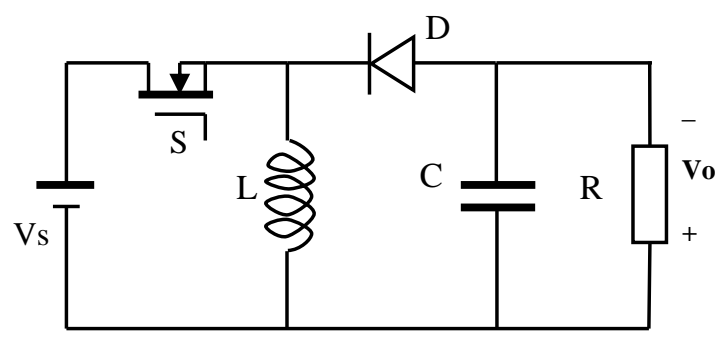

Gambar 2. Rangkaian Buck-boost converter

Parameter buck-boost converter dapat ditentukan pada Tabel 2 berikut. Persamaan (1) sampai (3) digunakan untuk menghitung parameter pada buck boost converter [8].
TABEL 2

PARAMETER BUCK-BOOST CONVERTER

\begin{tabular}{|c|c|}
\hline Parameter & Nilai \\
\hline Tegangan input $\left(\mathrm{V}_{\mathrm{S}}\right)$ & $36 \mathrm{~V}-51 \mathrm{~V}$ \\
\hline Frekuensi switching $\mathrm{PWM}(\mathrm{f})$ & $40 \mathrm{kHz}$ \\
\hline Tegangan output $\left(\mathrm{V}_{\mathrm{O}}\right)$ & $57,6 \mathrm{~V}$ \\
\hline Ripple arus $\left(\Delta \mathrm{I}_{\mathrm{L}}\right)$ & $20 \% \mathrm{~A}$ \\
\hline Ripple tegangan $\left(\Delta \mathrm{V}_{\mathrm{O}}\right)$ & $0,5 \% \mathrm{~V}$ \\
\hline Inductor $(\mathrm{L})$ & $153 \mu \mathrm{H}$ \\
\hline Capasitor $(\mathrm{C})$ & $363,423 \mu \mathrm{F}$ \\
\hline
\end{tabular}

$$
\begin{gathered}
V_{o}=-V_{s} \frac{D}{1-D} \\
L=\frac{(1-D)^{2} R}{2 f} \\
C=\frac{V_{o} D}{\Delta V_{o} R f}
\end{gathered}
$$

\section{B. Perancangan Inverter, LC filter, dan Transformator}

Rangkaian inverter satu fasa menggunakan empat buah IGBT untuk proses switching yang bekerja secara bergantian. Proses penyulutan IGBT dapat bekerja secara bergantian berdasarkan trigger SPWM yang masuk ke driver inverter oleh mikrokontroller. SPWM adalah jenis PWM yang dibangkitkan dengan cara membandingkan sinyal segitiga (carrier) dan sinyal sinus (refference) [9]. SPWM terdiri atas dua jenis, yaitu Bipolar SPWM yang memiliki satu sinyal referensi/sinus dan Unipolar SPWM yang memiliki dua sinyal referensi [10]. Pada inverter terdapat LC filter untuk mengurangi pengaruh harmonisa keluaran inverter. Dalam menganalisa dan menentukan nilai LC filter tergantung pada penyulutan komponen switching [9]. Persamaan (4) sampai (6) dapat digunakan untuk menghitung parameter inverter, LC filter, dan transformator [2]. Spesifikasi data inverter satu fasa, filter LC, dan transformator dapat ditentukan pada Tabel 3 berikut.

TABEL 3

PARAMETER INVERTER, LC FILTER, DAN TRANSFORMATOR

\begin{tabular}{|c|c|}
\hline Parameter & Nilai \\
\hline Tegangan input inverter $\left(\mathrm{V}_{\text {Baterai }}\right) \mathrm{DC}$ & $48 \mathrm{~V}$ \\
\hline Frekuensi switching SPWM (f) & $13 \mathrm{kHz}$ \\
\hline Frekuensi cut off $\left(\mathrm{f}_{\mathrm{C}}\right)$ & $2,5 \mathrm{kHz}$ \\
\hline Tegangan output inverter $\left(\mathrm{V}_{\text {Inverter }}\right) \mathrm{AC}$ & $33,94 \mathrm{~V}$ \\
\hline Tegangan output beban $\left(\mathrm{V}_{\text {Load }}\right) \mathrm{AC}$ & $220 \mathrm{~V}$ \\
\hline Angka transformasi trafo (a) & $1: 6,48$ \\
\hline Filter Induktor $\left(\mathrm{L}_{\mathrm{F}}\right)$ & $506 \mu \mathrm{H}$ \\
\hline Filter Kapasitor $\left(\mathrm{C}_{\mathrm{F}}\right)$ & $8 \mu \mathrm{F}$ \\
\hline
\end{tabular}




$$
\begin{gathered}
V_{\text {inverter }(A C)}=\frac{V_{\text {Baterai }(D C)}}{\sqrt{2}} \\
a=\frac{V_{\text {inverter }(A C)}}{V_{\text {Load }(A C)}} \\
f_{c}=\frac{1}{2 \pi \sqrt{L_{F} C_{F}}}
\end{gathered}
$$

\section{Perancangan Kontrol PI (Proportional-Integral)}

Kontrol PI merupakan kombinasi dari kontroller P dan kontroller I. Kontroller P digunakan untuk mengatur kenaikan nilai penguat (gain) sehingga mempercepat respon sistem sedangkan kontroler I untuk menghilangkan adanya nilai error dalam kondisi stabil/steady [11]. Terdapat beberapa Metode tuning Kontroller PI, seperti trial-error, analitik, ZieglerNichols, dan Cohen-Coon [12]. Kontrol tegangan output charging baterai pada sistem ini menggunakan kontrol PI menggunakan dua metode, yaitu metode analitik dimana penentuan nilai Kp (konstanta proporsional) dan Ki (konstanta integral) bergantung pada nilai L (delay transportation) dan ts (time settling) dan metode trial-error di mana nilai $\mathrm{Kp}$ dan $\mathrm{Ki}$ dapat diatur sesuai dengan respon yang diinginkan. Untuk mendapatkan nilai tersebut harus dilakukan simulasi untuk melihat karakteristik tegangan keluaran konverter yang digunakan. Karakteristik simulasi tegangan output pada buckboost converter menggunakan simulator PSIM dapat ditunjukkan pada Gambar 3.

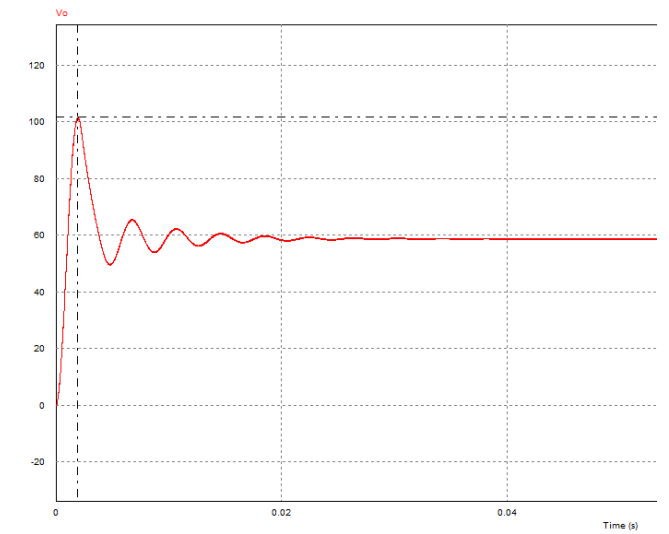

Gambar 3. Output simulasi tegangan buck-boost converter dengan simulator PSIM

Berdasarkan Gambar 3, untuk menentukan nilai Kp dan Ki dapat diperoleh data pada Tabel 4 sebagai berikut:

TABEL 4

PARAMETER KONTROL P

\begin{tabular}{|c|c|}
\hline \multicolumn{2}{|c|}{ PARAMETER KONTROL PI } \\
\hline Parameter & Nilai \\
\hline Tegangan maksimum $\left(\mathrm{V}_{\text {overshot }}\right)$ & $101,542 \mathrm{~V}$ \\
\hline Tegangan setpoint $\left(\mathrm{V}_{\text {setpoint }}\right)$ & $57,6 \mathrm{~V}$ \\
\hline Time Settling (ts) & 0,04 detik \\
\hline Konstanta Proporsional $(\mathrm{Kp})$ & 2,836265 \\
\hline Konstanta integral $(\mathrm{Ki})$ & 354,5331 \\
\hline
\end{tabular}

\section{PENGUJIAN DAN ANALISA}

\section{A. Simulasi Closeloop Buck-boost Converter}

Pada simulasi closeloop buck-boost converter akan dilakukan perbandingan respon tegangan output charging menggunakan kontrol PI dengan metode analitik berdasarkan data parameter pada Tabel 2 dan metode trial-error dengan nilai Kp dan Ki dapat disetting. Pada simulasi ini, metode trialerror di setting dengan nilai $\mathrm{Kp}=2,836265$ dan nilai $\mathrm{Ki}=1000,5331$. Hasil respon output tegangan kontrol PI dengan metode analitik dan metode trial error dapat dilihat pada Gambar 4 dan Gambar 5.

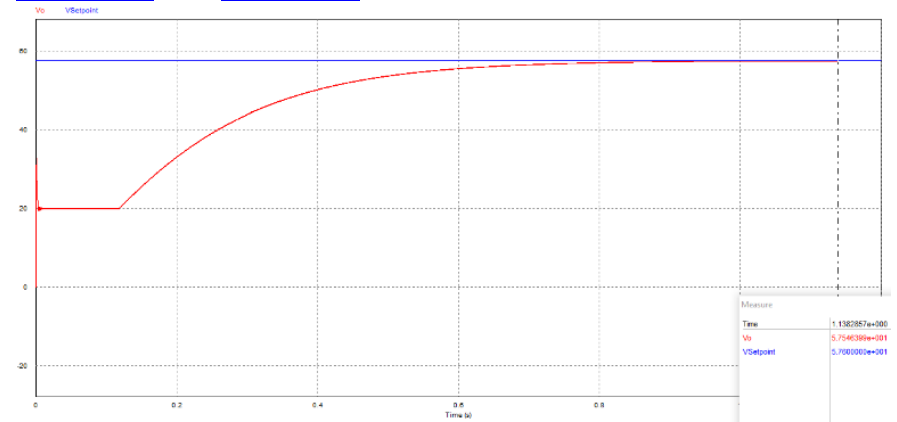

Gambar 4. Respon output tegangan kontrol PI metode analitik

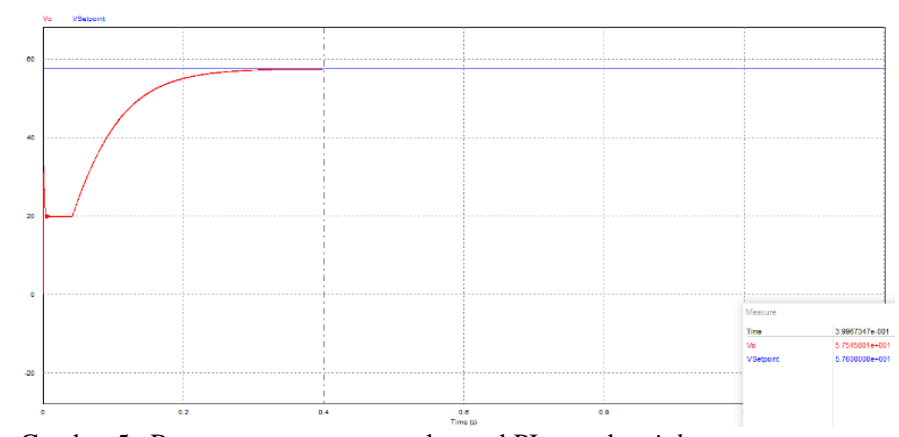

Gambar 5. Respon output tegangan kontrol PI metode trial error

Pada Gambar 4 dan Gambar 5 terlihat bahwa pengaturan duty cycle PWM menggunakan kontrol PI dapat mengurangi overshoot tegangan charging. Berdasarkan Gambar 4. terlihat bahwa respon output tegangan dengan kontrol PI menggunakan metode analitik dapat mengurangi overshoot tegangan. Tetapi respon output tegangan charging untuk mencapai steady state lambat, yaitu sekitar 1,13828 detik. Sedangkan pada Gambar 5. Respon output tegangan kontrol PI metode trial-error dengan nilai $\mathrm{Kp}=2,836265$ dan nilai $\mathrm{Ki}=1000,5331$ mampu mempercepat respon output tegangan charging untuk mencapai kondisi steady state sebesar 0,399967 detik.

\section{B. Simulasi Inverter Satu Fasa}

Pada simulasi inverter satu fasa menggunakan switching SPWM untuk sistem pensaklaran pada IGBT yang digunakan. SPWM yang digunakan berjenis unipolar SPWM. Berdasarkan data parameter inverter satu fasa pada Tabel 3 , bentuk gelombang tegangan output inverter $\left(\mathrm{V}_{\text {inverter }}\right)$ dengan teknik switching SPWM unipolar dapat dilihat pada Gambar 6. Pada Gambar 6 terlihat bahwa bentuk gelombang output masih jauh dari bentuk gelombang sinus dengan THD (total harmonic

Submitted: 03/08/2020; Revised: 23/10/2020; 
distorsion) tinggi dengan effisiensi yang rendah. Untuk mengatasi hal tersebut dipasang filter LC untuk mengurangi harmonisa sehingga bentuk gelombang output dapat mendekati bentuk sinus. Bentuk gelombang output tegangan setelah dipasang filter LC ( $\left.\mathrm{V}_{\text {filter}}\right)$ dapat dilihat pada Gambar 7. Untuk mencapai tegangan output nominal beban perencanaan $\left(\mathrm{V}_{\mathrm{Load}}\right)$, maka dipasang transformator step up sehingga mencapai tegangan output beban sebesar 220V AC. Bentuk gelombang output beban dapat dilihat pada Gambar 8 .

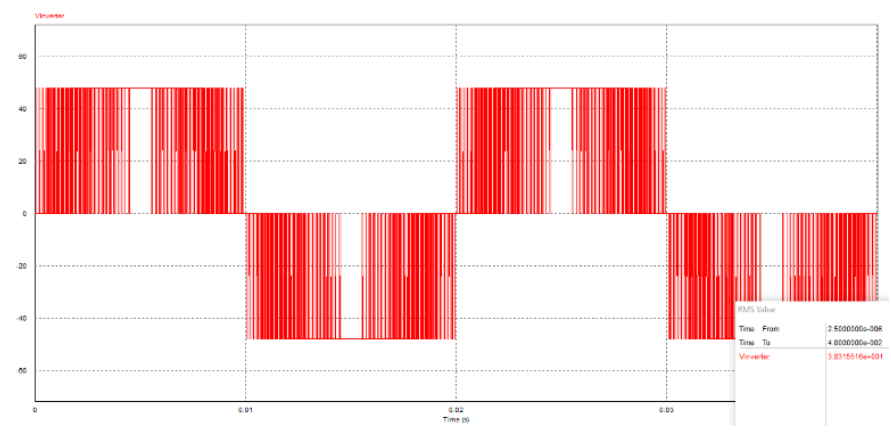

Gambar 6. Output tegangan inverter $\left(\mathrm{V}_{\text {inverter }}\right)$ dengan teknik switching SPWM unipolar

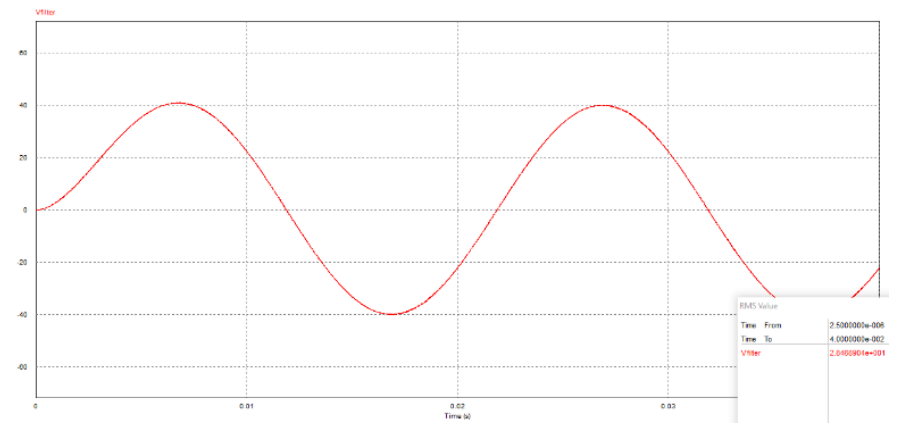

Gambar 7. Output tegangan setelah dipasang filter LC $\left(\mathrm{V}_{\text {filter }}\right)$

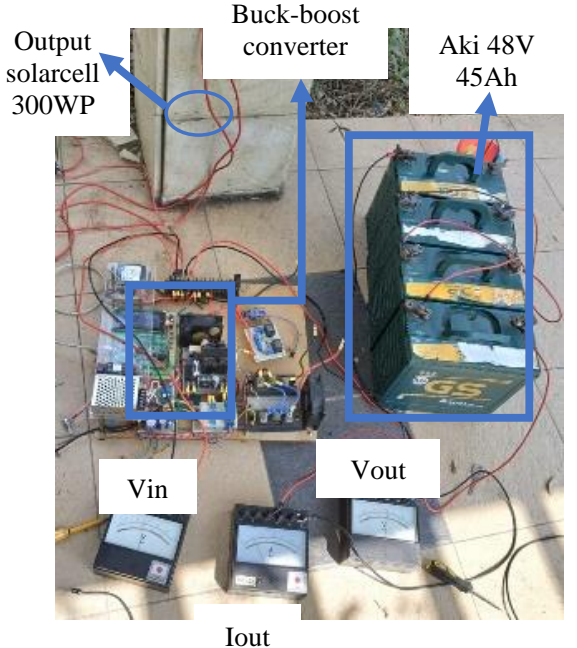

Gambar 8. Pengujian performa charging baterai

\section{Pengujian Charging Baterai Dengan Buck-boost Converter}

Pengujian ini bertujuan untuk mengetahui performa buckboost converter sebagai pengisi baterai 48V DC 45Ah. Pengujian ini mengggunakan sumber dari solar cell. Nilai SOC awal baterai sebelum di-charging yaitu $70 \%$ atau 49,9V DC. Pada Gambar 8 menunjukkan proses pengujian performa sistem charging baterai dengan buck-boost converter, Gambar 9 dan Gambar 10 menunjukan grafik hasil pengujian charging baterai.

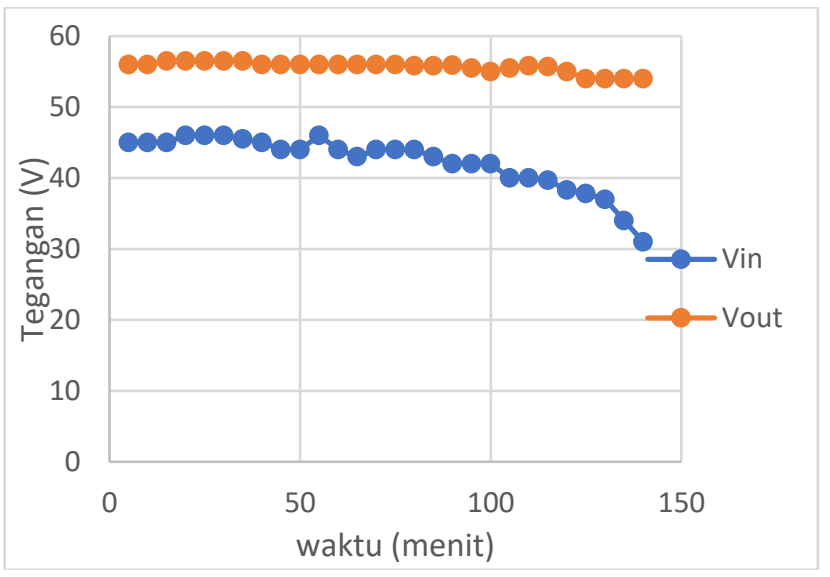

Gambar 9. Grafik hasil pengujian nilai tegangan input (Vin) dan tegangan output (Vout) charging baterai

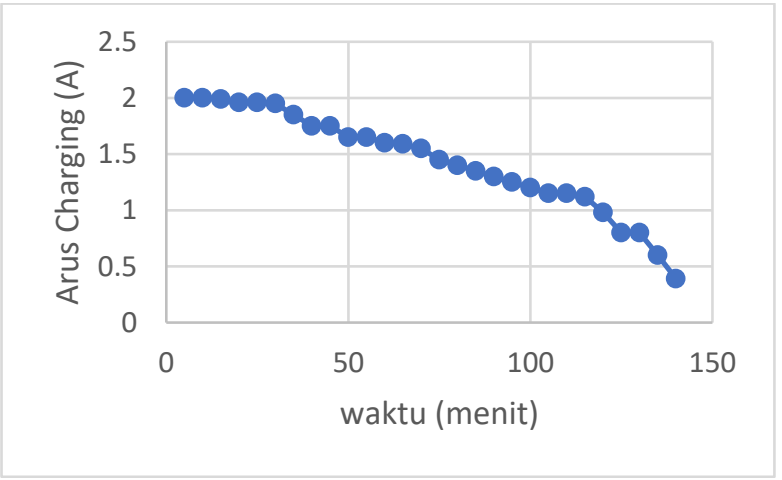

Gambar 10. Grafik hasil pengujian nilai arus charging (Io) baterai

Berdasarkan data grafik pengujian pada Gambar 9 terlihat bahwa performa converter yang digunakan untuk charging baterai dapat bekerja dengan baik, yaitu ketika terjadi perubahan nilai tegangan input (Vin), sistem dapat mempertahankan nilai tegangan output (Vo) charging antara 54V-56,5V DC. Pada Gambar 10 merupakan grafik data nilai arus output charging (Io) baterai. Berdasarkan hasil tersebut terlihat bahwa aki/baterai mengalami proses charging yang dapat dilihat pada penurunan nilai arus output charging dengan hasil nilai SOC akhir setelah proses charging 51,7V DC (full charging) 


\section{Pengujian Efisiensi Sistem Backup}

Pengujian ini dilakukan dengan menguji rangkaian sistem backup ketika diberi beban penuh. Beban yang digunakan pada pengujian ini adalah beban resistif berupa lampu pijar dengan nilai daya 50W, 220V AC. Pengujian ini dilakukan untuk mengetahui efisiensi (n) sistem beban backup sesuai daya beban yang direncanakan sesuai Tabel 1. Proses pengujian dapat dilihat pada Gambar 11. Hasil pengujian bentuk gelombang output tegangan inverter pada saat tegangan baterai $\left(\mathrm{V}_{\text {baterai }}\right)$ 24VDC sebelum dan sesudah difilter LC dapat dilihat pada Gambar 12 dan Gambar 13. Dari hasil pengujian tersebut dengan nilai beban dan tegangan masukan yang bervariasi maka didapatkan data pengujian seperti pada Tabel 5.

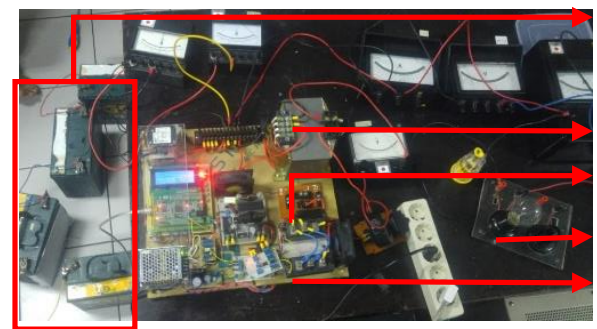

Baterai 48V DC, $45 \mathrm{Ah}$

transformator

LC filter

Beban lampu 50W Inverter modul

Gambar 11. Pengujian sistem backup

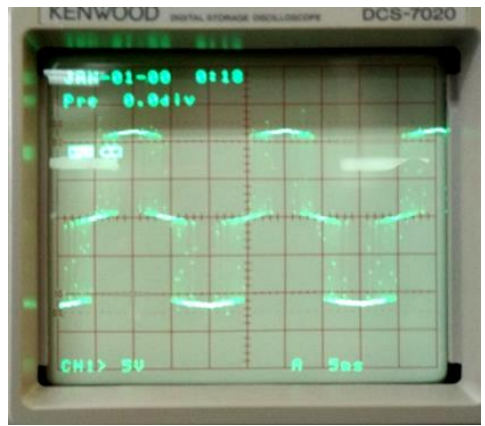

Gambar 12. Bentuk gelombang output tegangan inverter sebelum filter LC

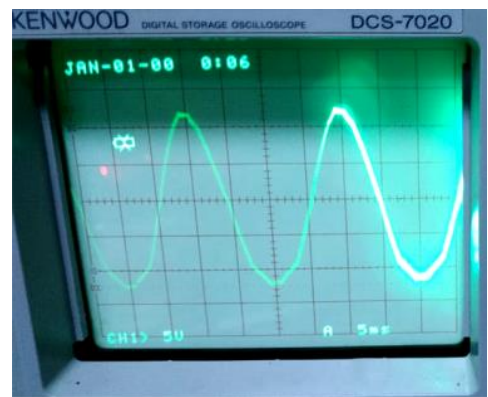

Gambar 13. Bentuk gelombang output tegangan inverter setelah filter LC

TABEL 5

DATA PENGUJIAN NILAI EFISIENSI SISTEM BACKUP

\begin{tabular}{|c|c|c|c|c|c|c|c|}
\hline $\begin{array}{c}\mathrm{V}_{\text {baterai }} \\
(\mathrm{V})\end{array}$ & $\begin{array}{c}\mathrm{V}_{\text {filter }} \\
(\mathrm{V}) \mathrm{AC}\end{array}$ & $\begin{array}{c}\mathrm{I}_{\text {filter }} \\
(\mathrm{A})\end{array}$ & $\begin{array}{c}\mathrm{V}_{\text {Load }} \\
(\mathrm{V})\end{array}$ & $\begin{array}{c}\mathrm{I}_{\text {Load }} \\
(\mathrm{A})\end{array}$ & $\begin{array}{c}\mathrm{P}_{\text {inverter }} \\
(\mathrm{W})\end{array}$ & $\begin{array}{c}\mathrm{P}_{\text {Load }} \\
(\mathrm{W})\end{array}$ & $\begin{array}{c}\mathrm{n} \\
(\%)\end{array}$ \\
\hline 12 & 5,38 & 1,15 & 50,31 & 0,11 & 6,187 & 5,5341 & 89,4 \\
\hline 24 & 12,29 & 1,83 & 121 & 0,16 & 22,49 & 19,4 & 86,1 \\
\hline 36 & 18,4 & 2,1 & 178 & 0,2 & 38,64 & 35,6 & 92,1 \\
\hline 48 & 25,86 & 2,8 & 201 & 0,24 & 72,408 & 48,24 & 66,6 \\
\hline
\end{tabular}

Submitted: 03/08/2020; Revised: 23/10/2020;

Accepted: 05/11/2020; Online first: 31/12/2020

http://dx.doi.org/10.46964/poligrid.v1i2.435
Berdasarkan data Tabel 5, $\mathrm{V}_{\text {filter }}$ merupakan tegangan inverter setelah filter LC, $\mathrm{I}_{\text {filter }}$ adalah arus inverter setelah filter LC, $\mathrm{I}_{\text {Load }}$ merupakan arus beban, $\mathrm{P}_{\text {inverter }}$ merupakan daya inverter setelah filter LC, $\mathrm{P}_{\text {Load }}$ merupakan daya beban, dan $\cos \Theta=1$ merupakan faktor daya karena menggunakan beban resistif. diatas dapat dilihat bahwa inverter mampu diberi beban sesuai perencanaan. Hal ini terlihat pada saat tegangan input dari baterai ( $\mathrm{V}_{\text {baterai }}$ ) sebesar $48 \mathrm{~V}$ DC output daya beban sebesar 48,24W dengan tegangan output beban ( $\left.\mathrm{V}_{\text {Load }}\right) 201 \mathrm{~V}$ AC yang seharusnya bernilai $220 \mathrm{~V}$ AC dengan selisih 19V AC. Berdasarkan data tersebut terlihat filter LC masih bersifat sebagai beban sehingga terjadi drop tegangan sebesar 19V AC di beban. Untuk menentukan nilai daya input dan daya output serta efisiensi daya $(\eta)$ dapat menggunakan Persamaan (7) sampai (9).

$$
\begin{gathered}
\text { Pinverter }=\text { V filter } \times \text { Ifilter } \times \cos \varphi \\
\text { Pload }=\text { Vload } \times \text { Iload } \times \cos \varphi \\
\eta=\frac{\text { Pload }}{\text { Pinverter }} \times 100 \%
\end{gathered}
$$

\section{KESIMPULAN}

Berdasarkan data hasil simulasi dapat membuktikan bahwa kontrol PI dengan metode trial-error pada saat nilai $\mathrm{Kp}=2,836265$ dan nilai $\mathrm{Ki}=1000,5331$ mampu memberikan respon output tegangan charging lebih baik dengan respon waktu untuk mencapai steady state 0,399967 detik sebesar dibandingkan metode analitik dengan respon waktu untuk mencapai steady state 1,13828 detik. Proses charging baterai sistem dapat mempertahankan nilai tegangan output (Vo) charging antara 54V-56,5V DC dan sistem mampu menyuplai beban sesuai perencanaan sebesar $50 \mathrm{~W}$ walaupun terjadi selisih drop tegangan sebesar 19V AC.

\section{UCAPAN TERIMA KASIH}

Dengan rasa puji syukur kehadirat Tuhan Yang Maha Esa dan tanpa menghilangkan rasa hormat yang mendalam, saya selaku penyusun dan penulis mengucapkan terimakasih yang sebesar-besarnya kepada pihak-pihak yang telah membantu penulis untuk menyelesaikan proyek akhir ini, penulis mengucapkan terimakasih kepada Dosen pembimbing proyek akhir dan seluruh Bapak dan Ibu dosen yang telah membimbing dan membekali ilmu kepada penulis selama menempuh pendidikan di kampus Politeknik Elektronika Negeri Surabaya (PENS).

\section{REFERENSI}

[1] S. Abdallah, Rancang Bangun Uninterruptible Power Supply (UPS) dengan Beban PLC, Tugas Akhir, Teknik Elektro Industri Politeknik Elektronika Negeri Surabaya, 2018.

[2] S. Utomo, Rancang Bangun Uninterruptible Power Supply (UPS) Beban Inkubator, Tugas Akhir, Teknik Elektro Industri Politeknik Elektronika Negeri Surabaya, 2016.

[3] S. R. Lee, S. H. Baek, C. Y. Won, "Serial multi-module UPS system control method considering battery module balancing", Prosiding International Telecommunications Energy Conference (INTELEC), 2015 
[4] S. Singh, S. Ghatakchoudhuri, "Average current feed-forward control for multi-modular single phase UPS inverters system", Prosiding 7th International Conference on Intelligent System, Modelling and Simulation, 2016.

[5] M. Aamir, S. Mekhilef, "Online transformerless uninterruptible power supply (UPS) system with a smaller battery bank for low power applications", IEEE Transactions on Power Electronics, vol. 32, 2017.

[6] F. Pires, D. Foito, A. Cordeiro, J. F. Silva, "A single-switch DC/DC buck-boost converter with extended output voltage", 7th International Conference on Renewable Energy Research and Aplications (ICRERA), 2018

[7] Hidayat, S. Mochamad, Rancamg Bangun Buck Boost Converter, Skripsi, Fakultas Teknik Program Studi Elektro Universitas Indonesia, Juni 2010.

[8] W. Hart, Power Electronics, McGraw Hill, 2011

[9] Algaddafi, K. Elnaddab, A. AlMamari, A. N. Esgiar, "Comparing the performance of bipolar and unipolar switching frequency to drive DCAC inverter" International Renewable and Sustainable Enery Conference (IRSEC), 2016.

[10] J. C. S. Rojas, D. A. B. López, D. M. B. Leguizamón, F. R. J. López, "Simulation of the model, design and control of a current source inverter with unipolar SPWM modulation", Prosiding IEEE 15th Brazilian Power Electronics Conference (COBEB) and 5th Southern Power Electronics Conference (SPEC), 2019.

[11] Laoprom, S. Tunyasrirut, W. Permpoonsinsup, D. Puangdownreong, "Voltage control with PI controller for four phase interleaved boost converter", Prosiding 16th International Conference on Electrical Engineering/Electronics, Computer, Telecommunications and Information Technology (ECTI-CON), 2019.

[12] Abdelhamid, L. Radhouane, A. Bilel, "Real time implementation of perturb and observe algorithm and PI controller for DC/DC converter", Prosiding 18th International Conference on Sciences and Technique of Automatic Control and Computer Engineering - STA, 2017

Submitted: 03/08/2020; Revised: 23/10/2020; 